\title{
Physiological changes in osmo and hydroprimed cucumber seeds germinated in biosaline water
}

\author{
Janete Rodrigues Matias², Renata Conduru Ribeiro ${ }^{2}$, Carlos Alberto Aragão 3 , \\ Gherman Garcia Leal Araújo² ${ }^{2}$ Bárbara França Dantas²*
}

\begin{abstract}
Biosaline agriculture has been a viable alternative for agricultural production in regions with lack of good quality water. To enable the cultivation of vegetables in high electrical conductivities, seed priming has been used to increase tolerance to stress caused by use of brackish water. We aimed to evaluate the efficiency of osmo and hydropriming in cucumber seeds cv. Caipira germinated biosaline in water, regarding germination and biochemical changes during the germinative process. The experimental design was totally randomized, with four replications of 50 seeds or 10 seedlings, in a factorial scheme 6x3; with six priming conditions (control, osmopriming during 24 and 48 hours, hydropriming with 1, 2 and 3 cycles of hydration-dehydration) and three biosaline water (fish farming biosaline wastewater) concentrations in distilled water $(0,50 \mathrm{e}$ $100 \%$ ). We evaluated the kinetics and percentage of germination; germinative metabolism and activity of antioxidant enzymes. According to the results, one hydropriming cycle is faster and more efficient to improve the performance of cucumber seedling in biosaline water and this can be used in substrate for germinating seeds of cucumber cv. Caipira.
\end{abstract}

Index terms: water reuse, Curcubitaceae, seedling development.

\section{Modificações fisiológicas em sementes de pepino osmo e hidrocondicionadas germinadas em água biossalina}

\begin{abstract}
RESUMO - A agricultura biossalina tem sido uma alternativa viável para a produção agrícola em regiões com escassez de água de boa qualidade. Para possibilitar o cultivo de hortaliças em condutividades elétricas elevadas, o condicionamento fisiológico de sementes tem sido utilizado para aumentar a tolerância destas ao estresse causado pela utilização de água salobra. Objetivouse avaliar a eficiência do osmo e hidrocondicionamento em sementes de pepino cv. Caipira em água biossalina, quanto à germinação e as modificações bioquímicas durante o processo germinativo. O delineamento foi inteiramente casualizado, com quatro repetições de 50 sementes ou 10 plântulas, em esquema fatorial 6x3; sendo seis condições de condicionamento fisiológico (controle, osmocondicionamento durante 24 e 48 horas; hidrocondicionamento com 1, 2 e 3 ciclos de hidratação e secagem) e três concentrações de água biossalina (água residuária de piscicultura) em água destilada (0, 50 e 100\%). Foram avaliados: porcentagem de germinação; crescimento inicial de plântulas; metabolismo germinativo e atividade de enzimas antioxidantes. De acordo com os resultados obtidos pode-se concluir que um ciclo de hidrocondicionamento é mais rápido e eficiente para melhorar o desempenho das plântulas de pepino em água biossalina, que pode ser utilizada no substrato de germinação de sementes de pepino cv. Caipira.
\end{abstract}

Termos para indexação: reuso de água, Curcubitacea, desenvolvimento de plântulas.

\section{Introduction}

Worldwide, soil salinity is a problem for agriculture in more than 8 million hectares; wich is $6 \%$ for the total agricultural area (Bot et al., 2000). The most serious salinity problems are held in the irrigated arid and semi-arid regions of the world, such as Northeastern Semiarid Region of Brazil. Soil salinity is also a serious problem in areas where groundwater

${ }^{1}$ Submitted on 06/01/2014. Accepted for publication on 09/12/2014. ${ }^{2}$ Embrapa Semiárido, Caixa Postal 23, 56302-970 - Petrolina, PE, Brasil. ${ }^{3}$ Departamento de Tecnologia e Ciências Sociais Universidade do Estado da of high salt content is used for irrigation (FAO, 2014). Because of the serious problems due to water scarcity, the search for alternatives which aims at better utilization of water resources has become extremely important. As an example, Israel has overcome this problem in an economically viable manner, which is the biosaline agriculture, enabling coexistence with water restriction (Rocha et al., 2010).

Biosaline agriculture aims to seek alternative use of salty water

Bahia, 48900-000 - Juazeiro, BA, Brasil.

*Corresponding author <barbara.dantas@embrapa.br> 
with efficient crop development and has been effective in salt affected regions, with use of sea water, brackish groundwater or wastewater (Al-Said et al., 2012). Although biosaline agriculture may be an alternative to crop production, in glycophytes, wich are most of crop species, it causes yield decrease by submitting seeds, transplants and growing plant to salt stress.

A way to increase seeds tolerance to abiotic stress, such as salt stress, is seed priming through various techniques of osmo or hydropriming used effectively in different crops (Sanchéz et al., 1997; Aragão et al., 2002; Azevedo Neto et al., 2005).

The contact of the seed with polyethylene glycol (PEG) solution during osmopriming, allows the occurance of all preparatory processes for seed germination, but prevents radicle emergence (Heydecker et al., 1975). Apparently, imposition of osmotic stress to seeds can induce tolerance to other stresses, including drought and salt tolerance. Primed seeds tend to germinate faster, since these have already started imbibition, requiring less water to complete germination (Mohammadi and Amiri, 2010).

At hydropriming, the amount of water absorbed by seeds is controlled by the length of time it remains in contact with a moist substrate (Farooq et al., 2010) or high relative humidity atmosphere, and subsequent drying. This technique results in increased seed germination and seedling emergence during re-imbibition (Ashraf and Foolad, 2005).

Within this approach, the aim of this work was to evaluate the effect of osmo and hydropriming in cucumber seeds germination (Cucumis sativus L. - Cucurbitaceae) cultivar Caipira, in fish farming biosaline wastewater.

\section{Material and Methods}

This study was carried out in 2012, with cucumber seeds (Cucumis sativus L. - Cucurbitaceae) cultivar Caipira. The experimental design was completely randomized with four replications of 50 seeds in a factorial scheme $6 \times 3$, regarding six priming conditions (control, osmopriming for 24 and 48 hours, 1, 2 and 3 cycles of hydropriming) and three biosaline water dilutions in distilled water $(0,50$ and $100 \%$ of biosaline water).

Osmopriming: seeds were placed in plastic boxes (gerboxes) on substrate blotter paper, soaked in -1.0 MPa PEG
6000 solution (Villela et al., 1991), at a volume equivalent to 2.5 times the substrate paper weight and kept in germinator for 24 and 48 hours at $25{ }^{\circ} \mathrm{C}$. After these periods, seeds were rinsed in running tap water to remove PEG solution, and dried at laboratory environment.

Hydropriming: was performed on gerboxes adapted with aluminum sieve with $40 \mathrm{~mL}$ of distilled water under the sieve and on it seeds were distributed and maintained for $8 \mathrm{~h}$ under laboratory conditions, characterizing hydration of seeds. For dehydration, water was replaced by $32 \mathrm{~g}$ silica, equivalent to $40 \mathrm{~mL}$ volume, for 12 hours, completing one cycle hydropriming. Three cycles of hydropriming were performed. Before and after each cycle, seeds water content was evaluated (Brasil, 2009).

Biosaline water $(B W)$ : after osmo and hydropriming, seeds were submitted to germination test in three different dilutions of BW in distilled water $(0,50$ and $100 \%)$, obtained from tanks used for raising Nile tilapia (Oreochromis sp). The chemical characteristic of BW can be observed in Table 1.

Germination and vigor variables accessed: seeds were evaluated for water content and percentage of normal and abnormal seedlings (Brasil, 2009). Seedlings were evaluated for shoot and root length and dry weight (Nakagawa, 1999).

Evaluation of germinative metabolism: embryo, cotyledons, shoots and roots were collected from seedlings with 2 and 4 days, and frozen at $-80^{\circ} \mathrm{C}$ until extraction. Total protein (TP); total soluble sugars (TSS); reducing sugars (RS); total amino acids (AA); catalase (CAT, E.C. 1.11.1.6) and ascorbate peroxidase (APX, EC 1.11.1.11) activities were quantified according to Ribeiro-Reis et al. (2012).

Statistical analysis: all data were subjected to analysis of variance and means were compared by Scott-Knott test at 5\% probability.

\section{Results and Discussion}

During hydropriming cycles, cucumber seeds water content ranged from $15 \%$ after hydration to $5 \%$ after dehydration. Water content of osmoprimed seeds reached values around $27 \%$ and decreased to $7 \%$, after drying, at both periods of osmopriming.

Table 1. Chemical characteristics of biosaline water (BW).

\begin{tabular}{|c|c|c|c|c|c|c|c|c|c|c|c|}
\hline \multicolumn{5}{|c|}{ Cations } & \multicolumn{5}{|c|}{ Anions } & \multirow[t]{2}{*}{$\mathrm{pH}$} & \multirow[t]{2}{*}{$\mathrm{CE}$} \\
\hline $\mathrm{Ca}^{2+}$ & $\mathrm{Mg}^{2+}$ & $\mathrm{Na}^{+}$ & $\mathrm{K}^{+}$ & $\Sigma^{+}$ & $\mathrm{CO}_{3}{ }^{2-}$ & $\mathrm{HCO}_{3}^{-}$ & $\mathrm{SO}_{4}{ }^{2-}$ & $\mathrm{Cl}^{-}$ & $\Sigma^{-}$ & & \\
\hline \multicolumn{11}{|c|}{$\mathrm{mmol}_{\mathrm{c}} / \mathrm{L}$} & $\mathrm{dS} . \mathrm{m}^{-1}$ \\
\hline 9.57 & 22.0 & 20.2 & 0.54 & 52.4 & 0 & 2 & 1.9 & 56 & 56.9 & 6.74 & 4.94 \\
\hline
\end{tabular}

Provided by the Laboratory of Soil, Water and Plants - Embrapa Tropical Semiarid.

Journal of Seed Science, v.37, n.1, p.007-015, 2015 
The germination process of cucumber cv. Caipira seeds was not affected by increasing salt concentration in germination medium. This also occurred in watermelon seeds cv. Crimson Sweet when subjected to domestic saline wastewater (Mota et al., 2011) or in squash and pumpkin seeds with fish farming brackish wastewater (Silva et al., 2014).

Although, a 4.94 dS.m ${ }^{-1}$ electrical conductivity was formerly considered damaging to Cucurbitaceae (Maas and Hoffman, 1977), recent literature showed cucumber seeds are tolerant up to $22 \mathrm{dS} \cdot \mathrm{m}^{-1}$ (Torres et al., 2000) and over $90 \%$ of cv. Caipira seeds germinate at $14 \mathrm{dS} . \mathrm{m}^{-1}$ (Matias et al., 2014).

Low electrical conductivities can induce an increased germination percentage and decreased number of abnormal seedlings by reducing seed damage by imbibition (Matthews and Powell, 2006). Thus, cucumber cv. Caipira seeds subjected to $50 \% \mathrm{BW}$ showed a higher percentage of normal seedlings when compared to seeds germinated in distilled water and subjected to a $100 \%$ BW. Furthermore, $100 \%$ BW induced an increase in cucumber seedlings root dry mass. In the highest salinity $(100 \% \mathrm{BW})$, there was dry mass accumulation in shoots compared to roots, emphasizing that salinity does not interfere with the growth of these seedlings (Table 2).

In general, cycles of hydropriming increased normal seedlings percentage when seeds germinated in distilled water (Table 2). Agreeing with these findings, one cycle of hydropriming was efficient to speed up and increase germination in cucumber cultivars Hatuey-1 and Japonés (Sanchez et al., 1997). In bean cv. Carioca seeds, hydropriming also was favorable, providing a faster germination (Aragão et al., 2002). Additionally, two and three cycles of hydropriming increased shoots dry mass in $100 \% \mathrm{BW}$, compared to other priming treatments (Table 2).

When cucumber seeds were primed for 24 hours, seedlings had higher shoot length growth when subjected to biosaline water, compared to other priming treatments. Evaluating shoot: root length ratio, all priming treatments increased shoot growth, when compared to unprimed seedlings. On the other hand, seeds hydro and osmopriming inhibited growth in root length of cucumber seedlings (Table 2).

Table 2. Germination and vigor of cucumber seedlings cv. Caipira germinated in different percentages of water biosaline (BW) and subjected to osmopriming for 24 and 48 hours (OP) and three cycles hydropriming (HP).

\begin{tabular}{|c|c|c|c|c|c|c|}
\hline BW & Control & $24 \mathrm{~h} \mathrm{OP}$ & 48h OP & 1Cycle HP & 2Cycle HP & 3Cycle HP \\
\hline$(\%)$ & \multicolumn{6}{|c|}{ Normal seedlings $(\%)$} \\
\hline 0 & $81.0 \mathrm{cB}$ & $79.5 \mathrm{bB}$ & $69.5 \mathrm{cC}$ & $90.0 \mathrm{aA}$ & $90.0 \mathrm{aA}$ & $91.0 \mathrm{aA}$ \\
\hline 50 & $94.0 \mathrm{aA}$ & $92.0 \mathrm{aA}$ & $93.5 \mathrm{aA}$ & $91.5 \mathrm{aA}$ & 94. $0 \mathrm{aA}$ & $92.5 \mathrm{aA}$ \\
\hline \multicolumn{6}{|c|}{$\mathrm{CV}(\%)=3.23$} & $76.0 \mathrm{bC}$ \\
\hline \multicolumn{7}{|c|}{ Abnormal seedlings (\%) } \\
\hline 0 & $19.0 \mathrm{aB}$ & $20.5 \mathrm{aB}$ & $30.5 \mathrm{aA}$ & $10.0 \mathrm{bC}$ & $10.0 \mathrm{bC}$ & $9.0 \mathrm{bC}$ \\
\hline 50 & $6.0 \mathrm{cA}$ & $8.0 \mathrm{bA}$ & $6.0 \mathrm{cA}$ & $8.5 \mathrm{bA}$ & $6.0 \mathrm{cA}$ & $7.5 \mathrm{bA}$ \\
\hline 100 & $11.5 \mathrm{bC}$ & $10.5 \mathrm{bC}$ & $\begin{array}{r}24.5 \mathrm{bA} \\
\mathrm{CV}(\%)=20\end{array}$ & $16.5 \mathrm{aB}$ & $18.0 \mathrm{aB}$ & $24.0 \mathrm{aA}$ \\
\hline \multicolumn{7}{|c|}{ Shoot length $(\mathrm{cm})$} \\
\hline 0 & $5.89 \mathrm{aB}$ & $6.69 \mathrm{bA}$ & $4.95 \mathrm{bB}$ & $5.66 \mathrm{aB}$ & $7.70 \mathrm{aA}$ & $7.36 \mathrm{aA}$ \\
\hline 50 & $6.64 \mathrm{aB}$ & $8.85 \mathrm{aA}$ & $6.58 \mathrm{aB}$ & $6.16 \mathrm{aB}$ & $6.16 \mathrm{bB}$ & $6.73 \mathrm{aB}$ \\
\hline 100 & $6.22 \mathrm{aA}$ & $6.37 \mathrm{bA}$ & $\begin{array}{c}6.95 \mathrm{aA} \\
\mathrm{CV}(\%)=9.7\end{array}$ & $6.28 \mathrm{aA}$ & $6.43 \mathrm{bA}$ & $6.04 \mathrm{bA}$ \\
\hline \multicolumn{7}{|c|}{ Root length $(\mathrm{cm})$} \\
\hline 50 & $9.80 \mathrm{aA}$ & $7.55 \mathrm{aB}$ & $6.32 \mathrm{aC}$ & $8.96 \mathrm{aA}$ & $7.79 \mathrm{aB}$ & $6.88 \mathrm{aC}$ \\
\hline 100 & $8.28 \mathrm{bA}$ & $6.59 \mathrm{bB}$ & $\begin{array}{c}6.30 \mathrm{aB} \\
\mathrm{CV}(\%)=8.9\end{array}$ & $7.83 \mathrm{bA}$ & $6.75 \mathrm{bB}$ & $5.78 \mathrm{bB}$ \\
\hline \multicolumn{7}{|c|}{ Shoot dry mass (mg) } \\
\hline 0 & $91.90 \mathrm{bC}$ & $91.75 \mathrm{cC}$ & $107.50 \mathrm{aB}$ & $96.75 \mathrm{bC}$ & $117.25 \mathrm{aA}$ & $123.50 \mathrm{bA}$ \\
\hline 50 & $110.25 \mathrm{aC}$ & $126.75 \mathrm{aB}$ & $116.00 \mathrm{aC}$ & $116.00 \mathrm{aC}$ & $129.00 \mathrm{aB}$ & $148.00 \mathrm{aA}$ \\
\hline \multicolumn{7}{|c|}{$\mathrm{CV}(\%)=7.63$} \\
\hline \multicolumn{7}{|c|}{ Root dry mass (mg) } \\
\hline 0 & $36.17 \mathrm{bA}$ & $44.25 \mathrm{aA}$ & $39.50 \mathrm{aA}$ & $29.00 \mathrm{bB}$ & $26.75 \mathrm{bB}$ & $21,80 \mathrm{cB}$ \\
\hline 50 & $28.50 \mathrm{cC}$ & $26.75 \mathrm{bC}$ & $24.75 \mathrm{bC}$ & $40.75 \mathrm{aB}$ & $40.75 \mathrm{aB}$ & $52.50 \mathrm{aA}$ \\
\hline 100 & $47.50 \mathrm{aA}$ & $27.75 \mathrm{bB}$ & $\begin{array}{r}22.50 \mathrm{bB} \\
\mathrm{CV}(\%)=13 .\end{array}$ & $27.00 \mathrm{bB}$ & $25.00 \mathrm{bB}$ & $30.50 \mathrm{bB}$ \\
\hline
\end{tabular}

Means followed by the same capital letter on the line, and lower case letter in the column do not differ statistically from each other. Scott-Knott test at $5 \%$ probability level was applied. 
Although fish farming effluents induce root growth in seedlings of cucurbits (Medeiros et al., 2010), cucumber seedlings that developed in BW with electrical conductivity of $4.9 \mathrm{dS} . \mathrm{m}^{-1}$, showed decreased root length (Table 2), as did gherkin seedlings in electrical conductivities greater than 2.15 dS.m-1 (Oliveira et al., 2013).

Substrate salinity initially changes absorption of water and nutrients, as well as, membrane permeability. By analyzing plant characteristics, one can realize that tolerance to salinity varies with stage of development in which the plant is in and if stress is imposed on a cell, a tissue or an organ of the individual. Cucumber seeds and seedlings showed different degrees of tolerance between organs and developmental stages (Table 2).

Conus et al. (2009) described salinity tolerance as the ability of plants to avoid, through an osmotic regulation, excessive amount of salt of substrate from reaching the plasma and to tolerate toxic and osmotic effects associated with increased salt concentration. Under stress conditions when seeds are primed, germination performance in adverse situation is favored, since seeds have already started soaking with lower osmotic potential and require less water to complete germination (Carvalho and Nakagawa, 2012). Due to a possible osmotic adjustment, which is a reduction of cell osmotic potential by accumulating compatible organic solutes with metabolism, seed priming has been considered an important enhancer of tolerance to salt and drought stress in plants (Azevedo Neto et al., 2005).

Accumulation of organic solutes, compatible with plant metabolism is an important mechanism of salt tolerance in plants. This mechanism promotes reduction of cell osmotic potential, thereby allowing an osmotic adjustment to the stress condition (Azevedo Neto et al., 2005), which may have occurred in cucumber cv. Caipira seedlings invigorated with hydropriming and subjected to salinity conditions during post-germinative growth (Tables 2-6).

Total protein (TP) in cotyledons, of cucumber seedlings with two days after sowing (DAS), increased significantly when they were not preconditioned and germinated in solutions of $50 \%$ BW (Table 3). This result was also observed in the hypocotyl-root axis. In 2 DAS cotyledons, under ideal conditions, the cycles of hydropriming caused a significant increase in TP concentration.

Mobilization of TP to the seedlings axis was affected by pre-treatments only in ideal germination conditions $(0 \%$ BW). Under these conditions, hydropriming induced a higher content in shoot TP, while osmopriming induced accumulation in roots TP content (Table 3 ). BW reduced TP degradation in cucumber cotyledons (Table 3 ).

Table 3. Content of total protein ( $\mu \mathrm{g} \cdot \mathrm{g}^{-1}$ of fresh weight) in cucumber seedlings cv. Caipira of 2 and 4 days after sowing (DAS), germinated in different percentages of biosaline water (BW) and subjected to osmopriming for 24 and 48 hours (OP) and three cycles hydropriming (HP).

\begin{tabular}{|c|c|c|c|c|c|c|}
\hline BW & Control & $24 \mathrm{~h} \mathrm{OP}$ & 48h OP & 1Cycle HP & 2Cycle HP & 3Cycle HP \\
\hline$(\%)$ & \multicolumn{6}{|c|}{ Cotyledons } \\
\hline 0 & $92.26 \mathrm{cD}$ & $136.96 \mathrm{aC}$ & $157.92 \mathrm{aB}$ & $189.82 \mathrm{aA}$ & $198.51 \mathrm{aA}$ & $192.62 \mathrm{aA}$ \\
\hline 50 & $248.30 \mathrm{aA}$ & $156.49 \mathrm{aB}$ & $173.99 \mathrm{aB}$ & $161.20 \mathrm{bB}$ & $181.72 \mathrm{aB}$ & $176.43 \mathrm{aB}$ \\
\hline \multicolumn{7}{|c|}{ Hypocotyl-root axis 2 DAS } \\
\hline 0 & $50.48 \mathrm{bA}$ & $65.54 \mathrm{aA}$ & $65.77 \mathrm{aA}$ & $86.79 \mathrm{aA}$ & $85.29 \mathrm{aA}$ & $64.70 \mathrm{aA}$ \\
\hline 100 & $47.32 \mathrm{bA}$ & $59.34 \mathrm{aA}$ & $\begin{array}{c}57.86 \mathrm{aA} \\
\mathrm{CV}(\%)=23.34\end{array}$ & $60.65 \mathrm{aA}$ & $63.98 \mathrm{aA}$ & $58.63 \mathrm{aA}$ \\
\hline \multicolumn{7}{|c|}{ Cotyledons 4 DAS } \\
\hline 0 & $56.43 \mathrm{aB}$ & $58.45 \mathrm{aB}$ & $36.84 \mathrm{aB}$ & $90.36 \mathrm{aA}$ & $52.98 \mathrm{aB}$ & $94.40 \mathrm{aA}$ \\
\hline 50 & $69.23 \mathrm{aA}$ & $78.45 \mathrm{aA}$ & $68.21 \mathrm{aA}$ & $53.28 \mathrm{bA}$ & $70.36 \mathrm{aA}$ & $76.37 \mathrm{aA}$ \\
\hline 100 & $68.51 \mathrm{aB}$ & $71.43 \mathrm{aB}$ & $\begin{array}{c}54.17 \mathrm{aB} \\
\mathrm{CV}(\%)=16.49\end{array}$ & $95.65 \mathrm{aA}$ & $63.93 \mathrm{aB}$ & $52.20 \mathrm{bB}$ \\
\hline \multicolumn{7}{|c|}{ Shoot 4 DAS } \\
\hline 50 & $5.08 \mathrm{aA}$ & $5.86 \mathrm{bA}$ & $6.08 \mathrm{bA}$ & $6.04 \mathrm{aA}$ & $4.91 \mathrm{aA}$ & $5.41 \mathrm{aA}$ \\
\hline 100 & $5.95 \mathrm{aA}$ & $6.73 \mathrm{bA}$ & $\begin{array}{c}4.42 \mathrm{bA} \\
\mathrm{CV}(\%)=21.27\end{array}$ & $7.23 \mathrm{aA}$ & $5.40 \mathrm{aA}$ & $4.23 \mathrm{aA}$ \\
\hline \multicolumn{7}{|c|}{ Root 4 DAS } \\
\hline 0 & $5.34 \mathrm{aB}$ & $4.48 \mathrm{aB}$ & $6.44 \mathrm{aB}$ & $14.09 \mathrm{aA}$ & $12.89 \mathrm{aA}$ & $10.78 \mathrm{aA}$ \\
\hline 50 & $5.55 \mathrm{aA}$ & $7.72 \mathrm{aA}$ & $7.65 \mathrm{aA}$ & $11.04 \mathrm{aA}$ & $6.98 \mathrm{bA}$ & $8.11 \mathrm{aA}$ \\
\hline 100 & $7.85 \mathrm{aA}$ & $6.58 \mathrm{aA}$ & $\begin{array}{c}10.29 \mathrm{aA} \\
\mathrm{CV} \%=33.11\end{array}$ & $11.57 \mathrm{aA}$ & $4.83 \mathrm{bA}$ & $6.75 \mathrm{aA}$ \\
\hline
\end{tabular}

Means followed by the same capital letter on the line, and lower case letter in the column do not differ statistically from each other. The Scott-Knott test at $5 \%$ probability level was applied. 
Both 2 and 4 DAS cotyledons of seedlings which were osmoprimed and germinated in distilled water showed a lower content of amino acids (AA) compared to other pretreatments. This content increased when osmoprimed seedlings were subjected to biosaline water (Table 4). During germination process, synthesis of new proteins relies on provision of adequate amino acids derived from breakdown of storage proteins (Kim et al., 2011). Furthermore, unprimed 2 DAS seedlings germinated under ideal conditions, showed lower AA content in embryonic axis than other treatments, different from what occurred in cotyledons (Table 4).

Seedlings with 4 DAS showed the accumulation of amino acids when grown from seeds primed for 24 hours. Seedlings not osmoprimed presented increased AA content, both in shoots and roots, as the concentration of BW increased, reaching values higher than twice in distilled water (Table 4). BW had positive effect on mobilization of seed reserves, which favored germination and seedling performance, leading to a better development in BW (Tables 2-6).

Table 4. Content of total aminoacids ( $\mu$ mol.g ${ }^{-1}$ of fresh weight) in cucumber seedlings cv. Caipira of 2 and 4 days after sowing (DAS), germinated in different percentages of biosaline water (BW) and subjected to osmopriming for 24 and 48 hours (OP) and three cycles hydropriming (HP).

\begin{tabular}{|c|c|c|c|c|c|c|}
\hline $\mathrm{BW}(\%)$ & Control & $24 \mathrm{~h} \mathrm{OP}$ & $48 \mathrm{~h} \mathrm{OP}$ & 1Cycle HP & 2Cycle HP & 3Cycle HP \\
\hline \multicolumn{7}{|c|}{ Cotyledons } \\
\hline 0 & $153.07 \mathrm{aA}$ & $120.25 \mathrm{bB}$ & $131.35 \mathrm{bB}$ & $163.43 \mathrm{aA}$ & $153.39 \mathrm{aA}$ & $145.83 \mathrm{aA}$ \\
\hline 50 & $155.44 \mathrm{aA}$ & $155.95 \mathrm{aA}$ & $171.41 \mathrm{aA}$ & $158.66 \mathrm{aA}$ & $156.52 \mathrm{aA}$ & $151.99 \mathrm{aA}$ \\
\hline 100 & $165.32 \mathrm{aA}$ & $144.27 \mathrm{aA}$ & $166.89 \mathrm{aA}$ & $159.65 \mathrm{aA}$ & $157.51 \mathrm{aA}$ & $73.61 \mathrm{bB}$ \\
\hline \multicolumn{7}{|c|}{$\mathrm{CV}(\%)=9.29$} \\
\hline \multicolumn{7}{|c|}{ Hypocotyl-root axis 2 DAS } \\
\hline 0 & $12.24 \mathrm{bB}$ & $68.02 \mathrm{aA}$ & $23.33 \mathrm{bB}$ & $46.64 \mathrm{bA}$ & $33.39 \mathrm{bB}$ & $55.27 \mathrm{aA}$ \\
\hline 50 & $98.32 \mathrm{aA}$ & $56.18 \mathrm{aB}$ & $65.06 \mathrm{aB}$ & $109.23 \mathrm{aA}$ & $91.83 \mathrm{aA}$ & $70.73 \mathrm{aB}$ \\
\hline 100 & $24.26 \mathrm{bA}$ & $27.96 \mathrm{bA}$ & $25.33 \mathrm{bA}$ & $25.00 \mathrm{cA}$ & $27.72 \mathrm{bA}$ & $31.50 \mathrm{bA}$ \\
\hline \multicolumn{7}{|c|}{$\mathrm{CV}(\%)=19.83$} \\
\hline \multicolumn{7}{|c|}{ Cotyledons 4 DAS } \\
\hline 0 & $114.24 \mathrm{aA}$ & $84.88 \mathrm{bB}$ & $73.37 \mathrm{bB}$ & $133.74 \mathrm{aA}$ & $121.40 \mathrm{aA}$ & $140.32 \mathrm{aA}$ \\
\hline 50 & $95.41 \mathrm{aB}$ & $116.79 \mathrm{aA}$ & $124.77 \mathrm{aA}$ & $88.83 \mathrm{bB}$ & $94.01 \mathrm{bB}$ & $66.21 \mathrm{bC}$ \\
\hline 100 & $109.47 \mathrm{aA}$ & $106.18 \mathrm{aA}$ & $72.21 \mathrm{bB}$ & $107.75 \mathrm{bA}$ & $93.19 \mathrm{bA}$ & $73.45 \mathrm{bB}$ \\
\hline \multicolumn{7}{|c|}{$\mathrm{CV}(\%)=10.43$} \\
\hline \multicolumn{7}{|c|}{ Shoot 4 DAS } \\
\hline 0 & $40.63 \mathrm{bC}$ & $25.66 \mathrm{bD}$ & $35.94 \mathrm{aC}$ & $98.53 \mathrm{aA}$ & $82.17 \mathrm{aB}$ & $45.81 \mathrm{aC}$ \\
\hline 50 & $56.51 \mathrm{aA}$ & $26.15 \mathrm{bB}$ & $43.09 \mathrm{aA}$ & $48.03 \mathrm{bA}$ & $26.81 \mathrm{bB}$ & $19.82 \mathrm{bB}$ \\
\hline 100 & $59.71 \mathrm{aA}$ & $55.10 \mathrm{aA}$ & $33.47 \mathrm{aB}$ & $21.79 \mathrm{cB}$ & $26.32 \mathrm{bB}$ & $20.72 \mathrm{bB}$ \\
\hline \multicolumn{7}{|c|}{$\mathrm{CV}(\%)=14.68$} \\
\hline \multicolumn{7}{|c|}{ Root 4 DAS } \\
\hline 0 & $7.46 \mathrm{cD}$ & $12.72 \mathrm{bD}$ & $29.94 \mathrm{aB}$ & $48.28 \mathrm{aA}$ & $20.56 \mathrm{aC}$ & $25.66 \mathrm{aB}$ \\
\hline 50 & $19.02 \mathrm{bA}$ & $20.81 \mathrm{aA}$ & $15.54 \mathrm{bA}$ & $24.48 \mathrm{bA}$ & $22.51 \mathrm{aA}$ & $22.62 \mathrm{aA}$ \\
\hline 100 & $37.8 \mathrm{aA}$ & $23.28 \mathrm{aB}$ & $18.95 \mathrm{bB}$ & $24.59 \mathrm{bB}$ & $21.71 \mathrm{aB}$ & $19.79 \mathrm{aB}$ \\
\hline \multicolumn{7}{|c|}{$\mathrm{CV}(\%)=13.96$} \\
\hline
\end{tabular}

Means followed by the same capital letter on the line, and lower case letter in the column do not differ statistically from each other. The Scott-Knott test at $5 \%$ probability level was applied.

Among the compounds predominant in seed reserves, carbohydrates act as an energy source in early seedling development (Carvalho and Nakagawa, 2012). Germination in BW, diluted or not, induced a higher content of reducing sugars (RS) in cotyledons of 2 DAS seedlings, except for those which were osmoprimed for 24 hours. Moreover, hypocotyl-root axis in this response was reversed for most pretreatments, in which 4 DAS cotyledons showed lower values RS compared to 2 DAS seedlings. Hydropriming $\mathrm{RS}$ resulted in higher levels in cotyledons of seedlings subjected to distilled water, whereas those maintained in $50 \%$ BW showed a high cotyledon RS content in all pretreatments. One cycle of hydropriming caused an increase in RS content in 2 DAS cotyledons and in 4 DAS shoots (Table 5).

Total soluble sugar (TSS) in cotyledons was lower in 2 DAS seedlings hydroprimed for one and three cycles and grown in 50\% BW solution (Table 6). Development on 50\% BW solution induced an increase in TSS levels in cotyledons and hypocotyl-root axis of unprimed seedlings. TSS content 
in 4 DAS cotyledons was lower compared to 2 DAS cotyledons. The level of TSS was higher in 4 DAS cotyledons of hydroprimed seedlings that developed in distilled water.
In pure BW, all pre-treatments induced increased levels of TSS, with the most significant increase after one cycle of hydropriming (Table 6).

Table 5. Content of total soluble sugars ( $\mu$ mol.g-1 of fresh weight) in cucumber seedlings cv. Caipira of 2 and 4 days after sowing (DAS), germinated in different percentages of biosaline water (BW) and subjected to osmopriming for 24 and 48 hours (OP) and three cycles hydropriming (HP).

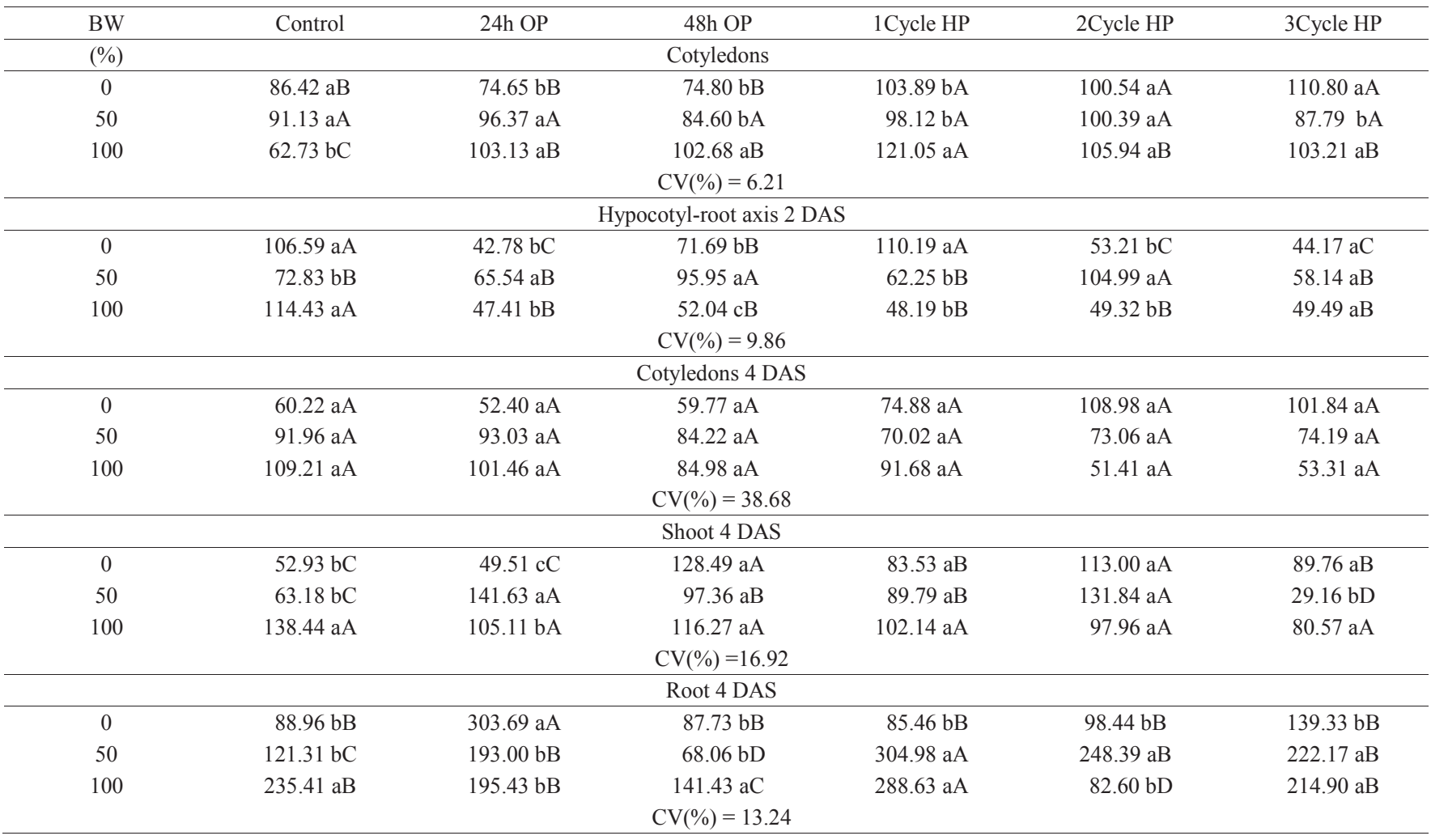

Means followed by the same capital letter on the line, and lower case letter in the column do not differ statistically from each other. The Scott-Knott test at $5 \%$ probability level was applied.

Reserve mobilization during germination, which provides energy for formation of the new plant, is a determining factor in seedling vigor produced by the end of the process (Carvalho and Nakagawa, 2012). Thus, during imposition of any stress, mobilization of storage substances of seeds should adjust so that normal, healthy and vigorous seedlings can be formed. In plants subjected to salt stress, accumulation of soluble sugars is a common process in the cells. Sugars have a role in osmotic adjustment, but also have indirect effects of protection as in stabilization of proteins (Bianchi et al., 1991). Priming, by imposing a moderate osmotic stress to seeds, induces the concentration of osmolites, such as sugars, to keep the cell's osmotic potential compatible with maintenance of stability of cell proteins, minimizing the loss of enzymatic activity or membrane integrity which occurs when there is water or saline stress (Gonçalves et al., 2007).
Catalase (CAT) prevents formation of reactive compounds, converting hydrogen peroxide into water and oxygen, which are non-reactive oxygen species (Nakada et al., 2011). The activity of CAT in the hypocotyl-root axis of 2 DAS seedlings was not affected by either methods of priming imposed on cucumber seeds (Table 7). This means these seeds showed no changes in oxidative stress, and therefore respiratory capacity, energy supply (ATP) and assimilates for seed germination may not be affected (Demirkaya et al., 2010). In 2 DAS cucumber seedlings cotyledons, CAT activity was higher than other treatments only for those who were osmoprimed for 48 hours or hydroprimed for two cycles and germinated in distilled water (Table 7), indicating that in 2 DAS cotyledons BW caused a mild salt stress, which was not alleviated by priming.

In other tissues and developmental stages differences in 
CAT activity were hardly observed (data not shown), indicating no increase in reactive oxygen species (ROS) or damage to cell membranes which could influence seedling performance.

The activity of ascorbate peroxidase (APX) in 2 DAS cotyledons was lower in seedlings subjected to $100 \%$ BW. Hydropriming in cotyledons induced a reduction in APX activity when subjected to BW. In 2 DAS seedlings hypocotyl-root axis, APX activity was low in relation to cotyledons. In hypocotyl-root axis of osmoprimed seedlings, APX activity was lower compared to non primed seedlings developed in 50\% BW (Table 7) and at 4 DAS the activity was null (data not shown). The decrease of APX activity when seeds were hydroprimed, may have been caused by decreased oxidative stress, resulting in an insufficient amount of ROS to induce the activity of this enzyme (Ribeiro-Reis et al., 2012).

Table 6. Content of reducing sugars ( $\mu \mathrm{mol} . \mathrm{g}^{-1}$ of fresh weight) in cucumber seedlings cv. Caipira of 2 and 4 days after sowing (DAS), germinated in different percentages of biosaline water (BW) and subjected to osmopriming for 24 and 48 hours (OP) and three cycles hydropriming (HP).

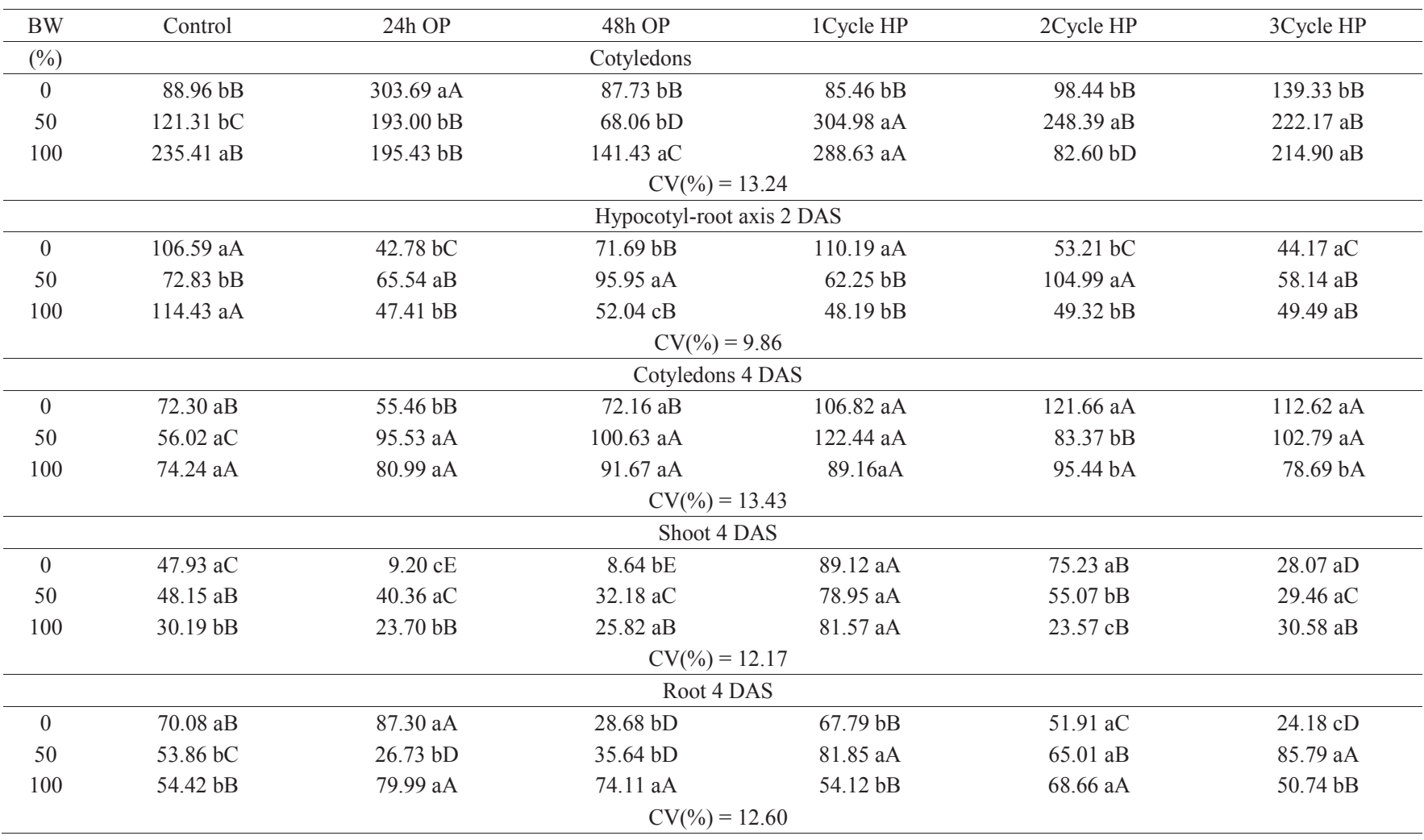

Means followed by the same capital letter on the line, and lower case letter in the column do not differ statistically from each other. The Scott-Knott test at $5 \%$ probability level was applied.

Considering antioxidative enzymes play vital roles in growth and development of early embryos, an increase in activity of these enzymes might result in vigorous growth and good crop establishment. Studies have shown priming affects activity of oxidative enzymes in the germination of seeds of different species (Ashraf and Foolad, 2005). However, not all cultures respond satisfactorily when developing in saline conditions, thus antioxidant defense mechanisms may provide a strategy to increase salt tolerance (Gonçalves et al., 2007).
In the present study, cucumber seedlings have grown satisfactorily in conditions that would be detrimental for the crop. When subjected to priming treatments, cucumber seeds showed higher tolerance to mild salt stress induced by the biosaline water, reflecting on seedling vigor. This study evaluated the germination and early seedling performance of cucumber for only eight days according to Brasil (2009). In order to check effects of priming treatments and biosaline water on transplants or adult plants, further studies should be conducted over a longer period of time. 
Table 7. Catalase- CAT activity ( $\mu \mathrm{mol} \mathrm{H}_{2} \mathrm{O}_{2} \min ^{-1} \cdot \mathrm{mg}$ protein ${ }^{-1}$ ) and ascorbate peroxidase- APX activity ( $\eta \mathrm{mol}$ ascorbate.min ${ }^{-1}$. mg proteín $\left.{ }^{-1}\right)$ in cucumber seedlings cv. Caipira of 2 days after sowing (DAS), germinated in different percentages of biosaline water (BW) and subjected to osmopriming for 24 and 48 hours (OP) and three cycles hydropriming (HP).

\begin{tabular}{|c|c|c|c|c|c|c|}
\hline BW (\%) & Control & $24 \mathrm{~h} \mathrm{OP}$ & $48 \mathrm{~h} \mathrm{OP}$ & 1Cycle HP & 2Cycle HP & 3Cycle HP \\
\hline \multicolumn{7}{|c|}{ Catalase activity } \\
\hline \multicolumn{7}{|c|}{ Cotyledons } \\
\hline 0 & $21.76 \mathrm{aB}$ & $24.82 \mathrm{aB}$ & $56.67 \mathrm{aA}$ & $28.49 \mathrm{aB}$ & $43.92 \mathrm{aA}$ & $27.58 \mathrm{aB}$ \\
\hline 50 & $29.54 \mathrm{aA}$ & $22.84 \mathrm{aA}$ & $36.20 \mathrm{bA}$ & $31.19 \mathrm{aA}$ & $48.11 \mathrm{aA}$ & $19.79 \mathrm{aA}$ \\
\hline 100 & $33.30 \mathrm{aA}$ & $17.79 \mathrm{aA}$ & $18.71 \mathrm{bA}$ & $25.98 \mathrm{aA}$ & $17.67 \mathrm{bA}$ & $11.15 \mathrm{aA}$ \\
\hline \multicolumn{7}{|c|}{$\mathrm{CV}(\%)=37.35$} \\
\hline \multicolumn{7}{|c|}{ Hypocotyl-root axis 2 DAS } \\
\hline 0 & $1.91 \mathrm{aA}$ & $2.13 \mathrm{aA}$ & $1.48 \mathrm{aA}$ & $2.54 \mathrm{aA}$ & $2.75 \mathrm{aA}$ & $2.59 \mathrm{aA}$ \\
\hline 50 & $2.16 \mathrm{aA}$ & $2.16 \mathrm{aA}$ & $2.24 \mathrm{aA}$ & $1.75 \mathrm{aA}$ & $1.80 \mathrm{aA}$ & $2.04 \mathrm{aA}$ \\
\hline 100 & $2.96 \mathrm{aA}$ & $1.65 \mathrm{aA}$ & $2.61 \mathrm{aA}$ & $2.29 \mathrm{aA}$ & $2.56 \mathrm{aA}$ & $2.52 \mathrm{aA}$ \\
\hline \multicolumn{7}{|c|}{$\mathrm{CV}(\%)=20.97$} \\
\hline \multicolumn{7}{|c|}{ Ascorbate peroxidase activity } \\
\hline \multicolumn{7}{|c|}{ Cotyledons } \\
\hline 0 & $46.57 \mathrm{aA}$ & $48.51 \mathrm{aA}$ & $51.15 \mathrm{aA}$ & $59.49 \mathrm{aA}$ & $58.12 \mathrm{aA}$ & $65.67 \mathrm{aA}$ \\
\hline 100 & $12.18 \mathrm{bA}$ & $8.21 \mathrm{bA}$ & $18.24 \mathrm{bA}$ & $12.52 \mathrm{bA}$ & $7.98 \mathrm{bA}$ & $7.15 \mathrm{bA}$ \\
\hline \multicolumn{7}{|c|}{$\mathrm{CV}(\%)=29.79$} \\
\hline \multicolumn{7}{|c|}{ Hypocotyl-root axis 2 DAS } \\
\hline 0 & $1.23 \mathrm{bA}$ & $1.33 \mathrm{aA}$ & $1.54 \mathrm{aA}$ & $1.28 \mathrm{aA}$ & $1.13 \mathrm{bA}$ & $1.29 \mathrm{aA}$ \\
\hline 50 & $1.86 \mathrm{aA}$ & $1.39 \mathrm{aB}$ & $1.13 \mathrm{bC}$ & $0.88 \mathrm{bC}$ & $0.82 \mathrm{cC}$ & $1.02 \mathrm{bC}$ \\
\hline 100 & $1.50 \mathrm{bA}$ & $1.34 \mathrm{aA}$ & $1.33 \mathrm{bA}$ & $1.42 \mathrm{aA}$ & $1.44 \mathrm{aA}$ & $1.47 \mathrm{aA}$ \\
\hline \multicolumn{7}{|c|}{$\mathrm{CV}(\%)=10.73$} \\
\hline
\end{tabular}

Means followed by the same capital letter on the line, and lower case letter in the column do not differ statistically from each other. The Scott-Knott test at $5 \%$ probability level was applied. Data were transformed by the equation $X=\sqrt{ } x$.

\section{Conclusions}

The cucumber seedlings were tolerant to salinity up to 4.9 $\mathrm{dS} . \mathrm{m}^{-1}$ imposed by biosaline water (BW). The BW may be used in germinating seeds of cucumber cv. Caipira and may be a viable alternative use for the production of seedlings through new studies.

One cycle of hydropriming can improve the overall performance of cucumber seedlings.

\section{References}

AL-SAID, F. A.; ASHFAQ , M.; AL-BARHI, M.; HANJRA, M.A.; KHAN, I. A. Water productivity of vegetables under modern irrigation methods in Oman. Irrigation and Drainage, v.61, n.4, p. 477-489, 2012. http:// onlinelibrary.wiley.com/doi/10.1002/ird.1644/full.

ARAGÃO, C.A.; DANTAS, B.F.; ALVES, E.; CORRÊA, M.R. Sementes de feijão submetidas a ciclos e períodos de hidratação-secagem. Scientia Agricola, v.59, n.1, p.87-92, 2002. http://www.scielo.br/pdf/sa/v59n1/8079.pdf

ASHRAF, M.; FOOLAD, M.R. Pre-sowing seed treatment - a shotgun approach to improve germination, plant growth, and crop yield under saline and non-saline conditions. Advances in Agronomy, v.88, p.223-271, 2005. http:// ac.els-cdn.com/S006521130588006X/1-s2.0-S006521130588006X-main. pdf?_tid=3fac8852-47b7-11e3-904a-00000aab0f6b\&acdnat $=1383833992$ e16d08759dccfa0e527a9dd6345849e4
AZEVEDO NETO, A.D.; PRISCO, J.T.; ENEAS-FILHO, J.; MEDEIROS J.V.R.; GOMES-FILHO, E. Hydrogen peroxide pretreatment induces saltstress acclimation in maize plants. Journal of Plant Physiology, v.162, p.1114-1122, 2005. http://ac.els-cdn.com/S0176161705000726/1-s2.0S0176161705000726-main.pdf?_tid=9bc0d724-4875-11e3-9b0d-00000aacb $35 \mathrm{f} \&$ acdnat $=13839157519 \mathrm{f} 120673 \mathrm{cdc} 3 \mathrm{ff} 3 \mathrm{f} 5 \mathrm{f} 5 \mathrm{c} 07 \mathrm{~d} 869 \mathrm{edaae} 9$

BIANCHI, G.; GAMBA, A.; MURELLI, C.; SALAMINI, F.; BARTELS D. Novel carbohydrate metabolism in the resurrection plant Cratero stigma plantagineum. The Plant Journal, v.1, p. 355-359, 1991. http://onlinelibrary. wiley.com/doi/ 10.1046/j.1365-313X.1991.t01-11-00999.x/pdf

BOT, A.; NACHTERGAELE, F.; YOUNG, A. Land resource potential and constraints at regional and country levels. Rome: FAO, 2000. (FAO.World Soil Resources Report, 90). ftp://ftp.fao.org/agl/agll/docs/wsr.pdf

BRASIL. Ministério da Agricultura, Pecuária e Abastecimento. Regras para análise de sementes. Ministério da Agricultura, Pecuária e Abastecimento. Secretária de Defesa Agropecuária. Brasília: Mapa/ACS, 2009. 395p. http:// www.agricultura.gov.br/arq_editor/file/2946_regras_analise_sementes.pdf

CARVALHO, N. M.; NAKAGAWA, J. Sementes: ciência, tecnologia e produção. 5.ed. Jaboticabal: FUNEP, 2012. 590p.

CONUS, L.A.; CARDOSO, P.C.; VENTUROSO, L.R.; SCALON, S.P.Q. Germinação de sementes e vigor de plântulas de milho submetidas ao stress e salino induzido por diferentes sais. Revista Brasileira de Sementes, v.31, n.4, p.67-74, 2009. http://www.scielo.br/pdf/rbs/v31n4/08.pdf 
DEMIRKAYA, M.; DIETZ, K.J.; SIVRITEPE, H.O. Changes in antioxidant enzymes during aging of onion seeds. Notula e Botanica e Hortiagrobotanici, v.38, n.1, p.49-52, 2010. http://www.notulaebotanicae.ro/index.php/nbha/ article/view/4575/4417

FAO - Food and Agriculture Organization of the United Nations, 2014. Soil salinity management. http:/www.fao.org/tc/exact/sustainable-agricultureplatform-pilot-website/soil-salinity-management/en/. Accessed on May, $17^{\text {th }}, 2014$.

FAROOQ, M.; WAHID, A.; AHMAD, N.; ASAD, S.A. Comparative efficacy of surface drying and re-drying seed priming in rice: changes in emergence, seedling growth and associated metabolic events. Paddy Water Environmental, v.08, n.01, p.15-22, 2010. http://link.springer.com/ article/10.1007/s10333-009-0170-1\#page-1

GONÇALVES, J.F.; BECKER, A.G.; CARGNELUTTI, D.; TABALDI, L.A.; PEREIRA, L.B.; BATTISTI, V.; SPANEVELLO, R.M.; MORSCH, V. M.; NICOLOSO, F.T.; SCHETINGER, M. R.C. Cadmium toxicity causes oxidative stress and induces response of the antioxidant system in cucumber seedlings. Brazilian Journal Plant Physiology, v.19, n.3, p.223232, 2007. http://www.scielo.br/scielo.php?script=sci_arttext\&pid=S1677$04202007000300006 \& \operatorname{lng}=\mathrm{en} \& \mathrm{nrm}=$ iso

HEYDECKER, W.; HIGGING, J.; TURNER, Y.J. Invigoration of seeds. Seed Science and Technology, v.3, p.881-888, 1975.

KIM, H.T.; CHOI, U.K.; RYU, H.S.; LEE, S.J.; KWON, O.S. Mobilization of storage proteins in soybean seed (Glycine max L.) during germination and seedling growth. Biochimica et Biophysica Acta, v.1814, p.11781187, 2011. http://www.ncbi.nlm.nih.gov/pmc/articles/PMC1877431/pdf/ amjpathol00113-0109.pdf8

MAAS, E.V., HOFFMAN, G.J. Crop salt tolerance, current assessment. Journal of the Irrigation and Drainage Division, v.103, n.2, p.115-134, 1977. http://www.waterrights.ca.gov/baydelta/docs/southerndeltasalinity/ hist_exhibits/1977bdh_p2ex1.pdf

MATIAS, J.R.; SILVA, T.C.F.S.; OLIVEIRA, G.M.; ARAGÃO, C.A.; DANTAS, B.F. Germinação de sementes de pepino cv. Caipira em condições de estresse hídrico e salino. Revista Sodebras, v.10, n.110, 2014. (in press)

MATTHEWS, S.; POWELL, A.A. Electrical conductivity vigour test: physiological basic and use. ISTA News Bulletin, n.131, p.32-35, 2006. https://www.seedtest.org/upload/cms/user/STI131April2006.pdf

MEDEIROS, D.C.; MARQUES, L.F.; DANTAS, M.R.S.; MOREIRA, J.N.; AZEVEDO, C.M.S.B. Produção de mudas de meloeiro com efluente de piscicultura em diferentes tipos de substratos e bandejas. Revista Brasileira de Agroecologia, v.5, n.2, p. 65-71, 2010. http://www.aba-agroecologia.org. br/ojs2/index.php/rbagroecologia/article/view/9619/pdf

MOHAMMADI, G.R.; AMIRI, F.The effect of priming on seed performance of canola (Brassica napus L.) under drought stress. American Eurasian Journal of Agricultural \& Environmental Sciences, v.2, n.9, p.202-207, 2010. http://www.idosi.org/aejaes/jaes9\%282\%29/16.pdf
MOTA, A.F.; ALMEIDA, J.P.N.; SANTOS, J.S.; AZEVEDO, J.; GURGEL, M.T. Desenvolvimento inicial de mudas de melancia 'Crimson sweet' irrigadas com águas residuárias. Revista Verde, v.6, n.2, p.98-104, 2011. http://www. gvaa.com.br/revista/index.php/RVADS/article/viewFile/628/pdf_175

NAKADA, P.G.; OLIVEIRA, J.A.; MELO, L.C.; GOMES, L.A.A.; VON PINHO, E.V.R. Desempenho fisiológico e bioquímico de sementes de pepino nos diferentes estádios de maturação, Revista Brasileira de Sementes, v.33, n.1,p.113-122, 2011. http://www.scielo.br/pdf/rbs/v33n1/13.pdf

NAKAGAWA, J. Testes de vigor baseados no desempenho das plântulas. In KRZYZANOSKI, F.C.; VIEIRA, R.D.; FRANÇA-NETO, J.B. (Ed.). Vigor de sementes: conceitos e testes. Londrina: ABRATES, 1999. p.2.1-2.24.

OLIVEIRA, F.N.; TORRES, S.B.; BENEDITO, C.P.; MARINHO, J.C. Comportamento de três cultivares de maxixe sob condições salinas. Semina: Ciências Agrárias, v.34, n.6, p.2753-2762, 2013. http://www.uel.br/revistas/ uel/index.php/semagrarias/article/view/12015/pdf_122

RIBEIRO-REIS, R.C.; DANTAS, B.F.; PELACANI, C.R. Mobilization of reserves and germination of seeds of Erythrina velutina Willd.(LeguminosaePapilionoideae) under different osmotic potentials. Revista Brasileira de Sementes, v.34, n.4, p.580-588, 2012. http://www.scielo.br/scielo. php?script $=$ sci_arttext\&pid $=$ S0101-31222012000400008\&lng $=$ en\&nrm=iso

ROCHA, F.A.; SILVA, J.O.; BARROS, F.M. Reuso de águas residuárias na agricultura: a experiência israelense e brasileira. Enciclopédia Biosfera, v.6, n.11, p.1-9, 2010. http://www.conhecer.org.br/enciclop/2010c/reuso\%20 de\%20aguas.pdf.

SANCHÉZ, J.A.; CALVO, E.; ORTA, R.; MURILO, Z. Tratamientos prégerminativos de hidratación-deshidratación pra semillas de pepino (Cucumis sativus L.). Acta Botánica Mexicana, n.38, p.13-20, 1997. http://www. redalyc.org/pdf/574/57403803.pdf

SILVA, J.E.S.B; BARBOSA, L.G.; SILVA, F.Z.; SILVA, T.B.; MATIAS, J.R.; ARAGÃO, C.A.; DANTAS, B.F. Produção de mudas de moranga e abóboras irrigadas com água biossalina. Scientia Plena, v.10, n.10, p.109906-1 - 109906 9, 2014. http://www.scientiaplena.org.br/sp/article/view/1949/1042

TORRES, S.B.; VIEIRA, E.L.; MARCOS-FILHO, J. Efeitos da salinidade na germinação e no desenvolvimento de plântulas de pepino. Revista Brasileira de Sementes, v.22, n.2, p.39-44, 2000

VILLELA, F.A.; DONI FILHO, L.; SEQUEIRA, E.L. Tabela de potencia osmótico em função da concentração de polietileno glicol 6000 e da temperatura. Pesquisa Agropecuária Brasileira, v.26, n.11-12, p.1957-1968, 1991. http://seer.sct.embrapa.br/index.php/pab/article/view/3549/882 